\title{
LECTURAS DE BIOÉTICA
}

\section{Las víctimas indirectas de la pandemia}

\author{
[Indirect victims of the pandemic] \\ Pedro Ernesto Vargas MD., F.A.A.P. \\ Pediatra y Neonatólogo, Consultorios Médicos Paitilla \\ Comunicación:Pedro Vargas / Correo electrónico: pedrovargas174@gmail.com
}

Recibido: 1 de junio 2021

Aprobado: 2 de junio 2021

Publicado: 24 de junio de 2021

DOI: $\underline{10.37980 / \text { im.journal. }}$ rspp. 20211768

Palabras clave: pandemia, victimas, disparidad, salud

Keywords: pandemic, victims, disparity, health

Reproducción: Artículo de acceso libre para uso personal e individual. Sujeto a derechos de reproducción para otros usos.

Aspectos bioéticos: El autor declara no tener conflictos de interés asociados a la confección de este manuscrito, y no se recibió financiamiento para la confección de este manuscrito.
A 15 meses de la pandemia, todavía no conocemos los resultados del cierre de los servicios de salud ni las consecuencias de los manejos de muchas manos en ese plato. Nos preocupa, con razón, la alarmante serie de consecuencias negativas sobre la economía y sobre la educación, pero, en la marcha forzada, la pandemia desnudó las serias y crónicas falencias éticas del sistema de salud nacional.

Se suspendieron las cirugías "electivas", la consulta externa, el seguimiento médico de los enfermos crónicos, la atención de los ancianos, el crecimiento y el desarrollo de los niños, los programas de vacunación pediátrica y del adulto, incluso, las "urgencias" priorizaron el problema respiratorio, esa cesta donde encontraríamos a los pacientes infectados y enfermos con COVID-19. No estábamos solos en estas directivas. Todo el globo terráqueo se sacudió, no solo con el paso devastador del virus, sino también con la insospechada prolongación de las medidas higiénicas, adoptadas frente a una epidemia de crecientes proporciones y veloz diseminación. Pero el manejo de cada país, aparte de dibujar su historia de aciertos y desaciertos, fue bastante similar.

Igualmente, la pandemia reveló la disparidad de la atención de la salud, que relegó a un plano distante e inferior la salud y la prevención, a los grupos menos privilegiados, dando paso desagradable y hasta detestable al privilegio mal ganado de políticos e ideologías. Para todo siempre hubo y hay una excusa, una razón, una burla. El descuido crónico a la dignidad humana se agudizó y, su espejo, la inequidad en las sociedades no solo empaña la condición humana, sino que también ha hecho relevante su sobrevivencia.

Escandalosas han sido las transacciones y los contratos para hacer hospitales, para comprar camas hospitalarias, ventiladores, monitores de signos vitales, oxímetros para leer la oxigenación, equipos de infusión intravenosa para medicamentos y fluidos vitales. Se abasteció alguna institución o varias, de medicamentos innecesarios mientras se desabastecían los necesarios y otros insumos. Le faltaron medicinas para enfermedades crónicas a muchos pacientes, como la hidroxicloroquina, ya mucho antes medicada y que desapareció de los anaqueles de las farmacias por promoverla como útil para la infección, cuando ya se probaba su ineficacia y riesgos; y, como si fuera poco, se distribuyó sin consentimiento ni una explicación integral de usos, beneficios, riesgos y costos.

Se burló un plan de vacunación donde se priorizara con sentido de justicia y discernimiento sanitarios, a quienes enfrentaban a diario el virus SARS-CoV-2, a los grupos de edad que producían los muertos de la pandemia, a los enfermos crónicos, a las mujeres embarazadas, $y$, a los maestros y profesores para promover un menor contagio para quienes aún no hay vacuna aprobada. Quienes dictaban las medidas de mitigación, severas muchas veces, fueron los primeros en burlarlas y salieron ilesos cada vez. $Y$, entre ellos, se introdujeron el tráfico de influencias, la suplantación y el abuso de la autoridad, la inconsistencia de la ley.

Se falsificaron resultados de pruebas de laboratorio, permisos para transitar cuando se recrudeció la cuarentena, se vendieron igualmente estos documentos al mejor postor y se 
establecieron en las playas y lugares de descanso las sedes de los negocios disfrazados de atención. La disparidad social y de poder adquisitivo hizo víctimas en ambos extremos, unos fueron ordeñados en sus bolsillos y otros hicieron las estadísticas de enfermedad y muerte, pero sobre todo se diezmaron 3 conceptos éticos: (1) la práctica médica basada en evidencia, (2) la distribución justa de los recursos, y (3) el consentimiento informado.'

Aunque parezca que he exagerado los eventos, que en la salud pública se han desnudado sin ambages y con agravio de las gentes, ellos son producto de la corrupción y la inequidad, que ya existían antes de marzo de 2020. Sin embargo, ellas también son algunas de las víctimas indirectas de la pandemia ${ }^{2}$, que no se cuidaron bien. Las rígidas medidas en la fase aguda de la pandemia también condicionaron la respuesta de las gentes a la atención de su propia salud y el temor les alejó de los centros de salud y hospitalarios. Pero, transcurrida esa fase aguda, no se justifica, ni aún frente a una situación semejante en la actual pandemia o en el futuro, abandonar por tanto tiempo las funciones de la atención de la salud que la población no solo reclama, sino que necesita. Como lo señalan Bruno y Rose, hay un delicado balance entre resguardar la salud del sistema sanitario frente al virus $y$, de forma inadvertida, causar daño a los pacientes no infectados por el SARS-CoV-2.

Los hospitales y los gobiernos tienen ahora el tiempo para redefinir sus propósitos, sus metas, sus recursos y asegurarse que de volver a ocurrir una sorpresa de tales proporciones, que la salud de la población no quedará a la deriva y a riesgo de sucumbir, no solo al agente infeccioso, sino también a la pobre planeación de salud, que rehuyendo a la evidencia científica de cómo, cuándo y dónde actuar se entrega a la improvisación, la anécdota y la desviación de los limitados recursos.

\section{Referencias}

1. Aquino YSJ \& Cabrera N: Hydroxychloroquine and COVID-19: critiquing the impact of disease public profile on policy and clinical decision-making. J Medical Ethics 2020.46(9) http://ds.doi. org/10.1136/medethics-2020-106306

2. Bruno B \& Rose S: Patiens Left Behind: Ethical Challenges in Caring for Indirect Victims of the Covid-19 Pandemic. Hasting Center Report July-August 2020: 19-23 